\title{
RELIGIOUS EDUCATION IN RUSSIA
}

\author{
Kurchenkov, Anatoly Alexandrovich ${ }^{1}$, Paukov, Andrey Andreevich ${ }^{2}$ \\ ${ }^{1}$ Professor of the Department of Physical Culture and Sports, Voronezh State University of \\ Engineering Technologies, Revolution Avenue, 19, Voronezh, Russia, \\ E-mail: kurwol1952@yandex.ru \\ ${ }^{2}$ Associate Professor of the Department of Physical Culture and Sports, Voronezh State University \\ of Engineering Technologies, Revolution Avenue, 19, Voronezh, Russia, \\ E-mail: fitwwc@mail.ru
}

\begin{abstract}
Radical socio-political transformations in Russia at the end of the XX century led to the activation of religion, the strengthening of its influence on various aspects of public life, including the sphere of education. The penetration of religion into the secular school, which until recently was extremely secularized, has generated and exacerbated the problem of "school and religion", which has been causing heated and not always constructive disputes in society for several years. The solution to this problem is not so much in the educational sphere, but in social, political, historical and other aspects. Nevertheless, it is necessary to develop and experimentally implement a new differentiated education strategy taking into account the prevailing historical realities. To this end, it seems appropriate to analyze the historical experience, take into account the educational practice of competing positions, but in fact approving various options for a single strategy of general religious studies education: confessional-oriented and secular-oriented.
\end{abstract}

Keywords: school, religion, education, government, church.

\section{INTRODUCTION}

The construction of a philosophical concept for the study of religious education currently seems to be very relevant, since such a concept will not only allow us to consider its state in modern Russia, but also provide an opportunity to determine the status and significance of religious education for our society, and to a certain extent give forecast of trends in its changes in the future. Theoretical philosophical analysis can serve as a basis for changing the view of religion and its role in public consciousness, for the formation of a model of state-confessional relations in this area.

Until now, the development of religious studies and religious education has significantly outstripped the adoption of managerial decisions in the designated area of social reality, which influenced the state education system, thereby leading to conflicts in the existing legal field. It should be emphasized that the protracted conflict of interpretations taking place in this area is due to history.

The methods of assimilation of religious values that have developed in Russian educational practice are reduced either to a liberal-secular model focused on preserving the "purity" of secular culture while postulating ideologically neutral academic religious studies, or to a model that cultivates religious meanings and values, which in a culturally interactive sense presupposes integration secular and religious cultural patterns with the priority of religious values. Such polarization in practice leads to the fact that either one or the other point of view wins.

\section{METHODOLOGY}

Historical, philosophical, pedagogical, psychological and culturological approaches to the study of this social 
phenomenon served as the methodological foundations of the philosophical study of the essence of religious studies and religious education and its implementation in the teaching process. The theoretical and methodological basis for considering religious education is the activity and system approaches, from the position of which it is viewed as a specific educational system and as the activity of the subjects included in it.

\section{RESULTS}

At present, the system of secular religious education in state and municipal educational institutions, as well as the system of religious education, has a developed legal basis based on the constitutional principle of the separation of religious associations from the state and the secular nature of education in state and municipal educational institutions enshrined in the Constitution of the Russian Federation.

Federal, regional bodies and educational institutions are called upon to consistently implement these principles, clearly dividing the spheres and functions of religious studies and religious education, developing them and protecting religious education from clerical influence and promoting, within the material possibilities and the existing legal field, religious associations in the development of religious education ...

The law enforcement practice in this area needs to be improved, since widespread deviations from the principle of the secular nature of education in state and municipal educational institutions of the Russian Federation, direct violations of it do not meet with due assessment and opposition from the executive authorities, education and justice authorities.

In Russian society, there is a need for religious education, for objective scientific knowledge about religion. Religious studies are an integral part of modern humanitarian knowledge.

A full-fledged religious education is designed to provide: a high level of culture, breadth of outlook and versatile education of a modern person, his understanding of the place and role of religion and specific religious associations in the history and culture of mankind and individual countries and peoples;

- Education on this basis of patriotism, respect for the past of their country, for the heritage of their ancestors;

- Formation of respect for human rights and freedoms, religious and national tolerance, respect for the religious beliefs and traditions of the peoples of Russia and the world, for the convictions and feelings of believers and non-believers;

- The necessary level of competence of various categories of employees, deputies of representative authorities, employees of educational and cultural institutions, law enforcement agencies, military personnel, business leaders, employees of public organizations, etc.

- Theoretical training of members of legislative bodies of various levels for the creative and competent implementation of legislative activity in the field of freedom of conscience and religion.

The Ministry of Education and Science of the Russian Federation and the Russian Academy of Education are called upon to make the necessary efforts to equip the educational process in general and professional secondary schools and higher educational institutions with special educational programs, textbooks and teaching aids that reflect the current level of scientific knowledge about religion and have their sources as the results of research in the field of religious studies conducted by academic institutes, universities and other scientific centers in Russia and abroad, as well as materials (information) submitted by religious associations of various faiths and not containing negative interpretations of other faiths and ideological beliefs.

Religious education, its material support, organization and maintenance are entirely the prerogative of religious associations of the respective confessions by virtue of the constitutional norm on their separation from the state. At the same time, the Russian state, to the extent of its material capabilities and within the legal framework, can assist religious associations in the development of their religious education systems by:

- Provision of tax benefits and benefits for the rental of premises for religious and general educational institutions under the care of confessions;

- Subsidies for the remuneration of teachers of subjects of the State educational standard in confessional general educational institutions;

- Allocation of buildings and premises to religious associations for free use or on the terms of preferential lease from the state or municipal fund for religious schools, catechetical centers and other forms of religious education for children and adults. 
The Ministry of the Russian Federation for Press, Television and Radio Broadcasting and Mass Communications, the Union of Journalists of Russia, and independent mass media are called upon to play an important role in the promotion and dissemination of scientific knowledge about religion, observing objectivity and tolerance in relation to both religious and various types of non-religious worldviews and beliefs, avoiding confessional or anti-religious bias.

\section{CONCLUSION}

Thus, institutions of professional religious education have all the rights and obligations established for religious organizations, and, at the same time, the rights and obligations of educational institutions. At the same time, there can be no state educational standards for the training of a professional clergyman. Let us note that the legislator has not changed the status of religious vocational education proper - the successful completion of the training of a future clergyman according to the programs of spiritual education does not give the right to a graduate of a spiritual educational institution to be considered a person with a higher education. But if, in addition to this spiritual education at the seminary, he received a higher education in theology, law, history, philosophy or any other educational program according to which the state educational standard is established, and if the seminary has the appropriate state accreditation, he is entitled to receive a state diploma.

\section{REFERENCE LIST}

Ashmarov I.A., Volkova E.A., Frolova E.V. (2015). To the Question of Formation of Trends in the Higher Education System within the Framework of Modern Globalization Processes. Modern problems of science and education. №. 1-1. P. 975. (In Russ.)

Bueva L. P. (1999) Spirituality and problems of moral culture. Materials of the "round table "'Spirituality, artistic creativity, morality". Voprosy Filosovii. №. 2. Pp. 3-9. (in Russ).

Dodonov V. I. (1997) The concept of spirituality and spirituality in the education of a person in the context of Russian religious philosophy of the late XIX-early XX centuries. Pedagogy and politics in education in Russia of the late XIX-early XX centuries. M. Ch. 1. Pp. 6-22. (in Russ).

Ershov B.A. (2010) The Russian Orthodox Church and secular power in the Voronezh province in the XIX early XX centuries. GOU VPO "Voronezh State Technical University". Voronezh. 167 p. (in Russ).

Ershov B.A. (2010) The system of spiritual education in Voronezh province in the 19th century. Education and Society. №. 5 (64). Pp. 105-108. (in Russ).

Ershov B.A., Ashmarov I.A. (2018) Interaction Of The Orthodox Church And The State In Russia At The Present Stage. Bulletin Social-Economic and Humanitarian Research. № 2. Pp. 19-24. (In Eng.)

Ershov B.A., Ashmarov I.A., Danilchenko S.L. (2018) The Development Of Russian Church Architecture In The 1990s-2017: The State And Prospects. Open archive article in № 1. 06.05.2018. (In Eng.)

Ershov B.A., Ashmarov I.A., Drobyshev A.V., Zhdanova T.A., Buravlev I.A. (2017) Property And Land Relations Of Russian Orthodox Church And State In Russia. The European Proceedings of Social \& Behavioural Sciences. Pp. 324-331. (In Eng.)

Ershov B.A., Fursov V.N. (2018) The Russian Church in the State Mechanism of Russia. Bulletin SocialEconomic and Humanitarian Research. № 1. Pp. 32-37. (in Engl).

Ershov B.A., Perevozchikova L.S., Romanova E.V. (2019) Globalization and Intensification of Spiritual Values in Russia in the Philosophical Aspect. 6th International Conference on Education and Social Sciences Abstracts \& Proceedings. Pp. 208-212. (in Engl).

Ershov B.A., Perevozchikova L.S., Romanova E.V., Ashmarov I.A. (2019) The Concept of Spirituality in Social Philosophy. Smart Innovation, Systems and Technologies. T. 139. Pp. 688-694. (in Engl).

Gusev G. V. (1999) Social pedagogy of the Orthodox Church. Pedagogy. №. 3. Pp. 92-96. (in Russ).

Hasanov Z. T. (2003) Moral, ethical and religious foundations of the education of patriotism and religious tolerance. Pedagogy. №. 5. Pp. 18-26. (in Russ). 
Kostikova M. N. (1999) On the question of the modern history of professional religious education. The state, religion, the Church in Russia and abroad: Information and analytical bulletin. №. 3. Moscow: Publishing House of the RAGS. Pp. 123-143. (in Russ).

Kudrina T. A., Kolodin A.V. (2001) The problem of "school and religion" in the system of state-church relations. The state, religion, and the Church in Russia and abroad. Informational and analytical bulletin. №. 1. Moscow: RAGS Publishing House. Pp. 3-14. (in Russ).

Likhachev A. E. (2001) Education and spirituality (notes of an Orthodox teacher). Pedagogy. №. 3. Pp. 3336. (in Russ).

Lukhovitsky B. B. (2005) Religious education in a secular school. The limits of secularism: a public discussion about the principle of secularism of the state and about the ways of realizing freedom of conscience. Moscow: Sova Center. Pp. 146-161. (in Russ).

Mitrokhin JI. H. (1999) School and religion. "Philosophy, culture and education" (materials of the "round table"). Voprosy Filosovii. №. 3. Pp. 31-33. (in Russ).

Nysanbayev A., Kurganskaya V. (2001) Philosophy and education: the search for consent. Higher education in Russia. №. 1. Pp. 39-52. (in Russ).

Plekhanov E. (2003) Religious education in the national pedagogical culture. Alma mater. №. 10. Pp. 26-32. (in Russ).

Romanova E.V., Perevozchikova L.S., Ershov B.A. (2017) The Lifestyle of the Human Being in the Information Society. 3rd International Conference on Advances in Education and Social Sciences Proceedings of ADVED Pp. 950-954. (in Engl).

Vyazemsky E. E. (1999) The education system in the Russian Federation (figures, facts, trends). Fundamentals of State and Law. №. 7. Pp. 62-63. (in Russ). 